\title{
A Test Method to Evaluate Salt Tolerance of Ornamentals
}

\author{
Kimberly Moore ${ }^{1,4}$, Charles Wajsbrot ${ }^{2}$, Cristina Burgart ${ }^{2}$, and \\ Luci Fisher $^{3}$
}

AdDitional INDEX WORDs. electrical conductivity, $\mathrm{Na}, \mathrm{NaCl}$, sodium

SUMMARY. Because salts in irrigation water decrease plant growth, we wanted to develop a quick and easy method for evaluating salt tolerance that could be used in the greenhouse. Using plastic containers with lids, sea salt, and rooted cuttings, we monitored changes in plant quality, growth, and leaf water potential as electrical conductivity (EC) and sodium (Na) levels increased. In the first of two experiments, we compared sea hibiscus (Hibiscus tilliaceus) leaf water potential and plant quality in solutions with an EC of $0,2.1,4.2,6.1$, or $8.2 \mathrm{dS} \cdot \mathrm{m}^{-1}(0,240,420,610$, or 1010 $\left.\mathrm{mg} \cdot \mathrm{L}^{-1} \mathrm{Na}\right)$. After 14 days, sea hibiscus quality in solutions with an EC of 6.1 or 8.2 $\mathrm{dS} \cdot \mathrm{m}^{-1}$ was less than plants in solutions of $0,2.1$, or $4.2 \mathrm{dS} \cdot \mathrm{m}^{-1}$. There was no difference in quality among plants in $0,2.1$, or $4.2 \mathrm{dS} \cdot \mathrm{m}^{-1}$ solutions. To test this method, in Expt. 2, we compared coleus (Coleus $\times$ bybridus), copperleaf (Acalypha wilkesiana), ficus (Ficus benjamina), jasmine (Jasminium multiflorum), and plumbago (Plumbago auriculata) plant quality and growth in solutions with an EC of $0,1.3,2.1,4.2,5.6$, or $6.1 \mathrm{dS} \cdot \mathrm{m}^{-1}\left(0,170,240,420,520\right.$, or $\left.610 \mathrm{mg} \cdot \mathrm{L}^{-1} \mathrm{Na}\right)$. Coleus quality declined at an EC greater than $1.3 \mathrm{dS} \cdot \mathrm{m}^{-1}$, whereas jasmine and plumbago quality declined at an EC greater than $2.1 \mathrm{dS} \cdot \mathrm{m}^{-1}$ Copperleaf and ficus declined at an EC greater than $4.2 \mathrm{dS} \cdot \mathrm{m}^{-1}$. Plant response did vary with low to medium salt-tolerant plants tolerating at an EC up to 1.3 and $170 \mathrm{mg} \cdot \mathrm{L}^{-1} \mathrm{Na}$, whereas plants with a greater salt tolerance tolerated at EC and Na values up to 4.2 $\mathrm{dS} \cdot \mathrm{m}^{-1}$ and $420 \mathrm{mg} \cdot \mathrm{m}^{-1} \mathrm{Na}$, respectively. The use of this method benefits growers by determining upper EC and $\mathrm{Na}$ limits when faced with poor-quality water resulting from saltwater intrusion or when using reclaimed wastewater with greater EC and Na levels.

M ost recommendations about salt tolerance state that plants have low, medium, or high salt tolerance. Salt tolerance can be assessed in terms of plant growth rate, which is appropriate for many plant species (Munns, 2002). We expect to observe a decrease in growth and yield when roots are exposed to high salt levels, because the water potential is reduced in the soil, leading to a reduction in water uptake

Received for publication 28 Mar. 2019. Accepted for publication 20 May 2019.

Published online 24 June 2019.

Department of Environmental Horticulture, University of Florida, IFAS, Fort Lauderdale Research and Education Center, 3205 College Avenue, Davie, FL 33314

We thank the Horticulture Research Institute and Florida Nursery Grower and Landscape Association for funding to support this work (FLA-FTL-005315).

${ }^{1}$ Professor

${ }^{2}$ Former graduate student.

${ }^{3}$ Biological scientist.

${ }^{4}$ Corresponding author. E-mail: klock@ufl.edu.

This is an open access article distributed under the CC BY-NC-ND license (https://creativecommons.org/ licenses/by-nc-nd/4.0/).

https://doi.org/10.21273/HORTTECH04365-19 by the roots (Boursiac et al., 2005). Under normal growing conditions, the water potential in root cells is less than in the outer environment, and water moves into the roots (Luu and Maurel 2005; Tournaire-Roux et al., 2003). However, when the salt concentration is greater outside the plant root than some arbitrary value, salt stress occurs.

Most salt stress in nature is a result of the presence of Na salts (Levitt, 1980). Some water sources may have high Na levels resulting from to saltwater intrusion, the use of reclaimed wastewater, or seasonal variation from snowmelt products. Well water in Massachusetts' greenhouses had
$\mathrm{Na}$ levels ranging from $\mathrm{l}$ to 544 $\mathrm{mg} \cdot \mathrm{L}^{-1}$ whereas Na levels in wastewater range from 124 to $384 \mathrm{mg} \cdot \mathrm{L}^{-1}$ (Karleskint et al., 2011). Wastewater effects on field, forage, wetland, forest, and ornamental crops have been the subject of many investigations, with varied plant response resulting from differences in the salt tolerance of the plants investigated (Brister and Schultz, 1981; Day et al., 1981; Fitzpatrick, 1985; Fitzpatrick et al., 1986; Yeager et al., 2009).

Because plant response mechanisms involved in salt tolerance are complicated, there is no standard method for evaluating salt tolerance. One method for measuring salt tolerance is to correlate changes in yield associated with soil EC levels. Other methods monitor changes in osmotic potential in the leaves or the uptake and translocation of $\mathrm{Na}$ in the plants (Levitt, 1980; Niu and Cabrera, 2010). However, these methods may be challenging to implement in a greenhouse setting because of the lack of resources or the need for specialized equipment.

We questioned whether we could design a quick and easy test to screen plants based on EC and $\mathrm{Na}$ levels in solution that would confirm observational data classifying plants as low, medium, or high salt-tolerant. We monitored changes in leaf water potential and plant quality of sea hibiscus, a high salt-tolerant plant, exposed to increasing $\mathrm{EC}$ and $\mathrm{Na}$ levels. Because measuring water potential is impractical for a grower, for additional testing we compared plant quality and growth of low to medium salt-tolerant plants-specifically, coleus, copperleaf, ficus, jasmine, and plumbago - in solutions exposed to increasing EC and $\mathrm{Na}$ levels.

\section{Material and methods}

Expт. 1. Rooted cuttings of sea hibiscus were placed randomly into individual $42-\mathrm{fl} \mathrm{oz}$ containers

\begin{tabular}{llll}
\hline $\begin{array}{l}\text { Units } \\
\text { To convert U.S. to SI, } \\
\text { multiply by }\end{array}$ & U.S. unit & SI unit & $\begin{array}{l}\text { To convert SI to U.S., } \\
\text { multiply by }\end{array}$ \\
\hline 100 & $\mathrm{bar}$ & $\mathrm{kPa}$ & 0.01 \\
29.5735 & $\mathrm{fl} \mathrm{oz}$ & $\mathrm{mL}$ & 0.0338 \\
0.0929 & $\mathrm{ft}^{2}$ & $\mathrm{~m}^{2}$ & 10.7639 \\
3.7854 & $\mathrm{gal}$ & $\mathrm{L}$ & 0.2642 \\
1 & $\mathrm{mmho} / \mathrm{cm}$ & $\mathrm{dS} \cdot \mathrm{m}^{-1}$ & 1 \\
28.3495 & $\mathrm{oz}$ & $\mathrm{g}$ & 0.0353 \\
1 & $\mathrm{ppm}$ & $\mathrm{mg} \cdot \mathrm{L}^{-1}$ & 1 \\
$\left({ }^{\circ} \mathrm{F}-32\right) \div 1.8$ & ${ }^{\circ} \mathrm{F}$ & ${ }^{\circ} \mathrm{C}$ & $\left({ }^{\circ} \mathrm{C} \times 1.8\right)+32$ \\
& & & \\
\hline
\end{tabular}




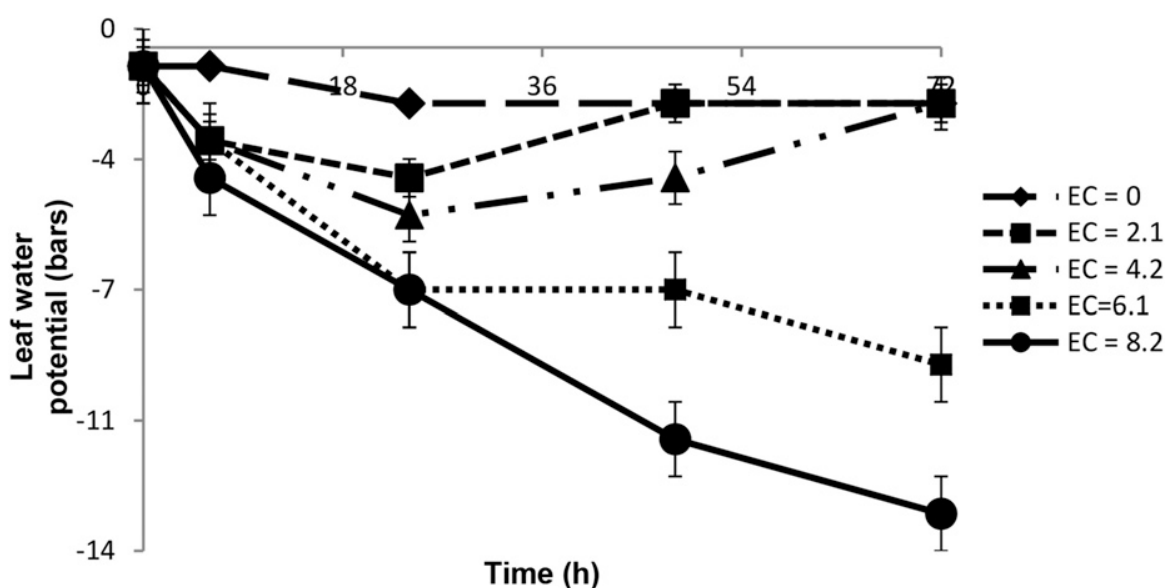

Fig. 1. Change in leaf water potential of sea hibiscus over $72 \mathrm{~h}$ for plants grown in deionized water with salt added to create an electrical conductivity (EC) of $0,2.1$, $4.2,6.1$, or $8.2 \mathrm{dS} \cdot \mathrm{m}^{-1}\left(0,240,420,510\right.$, or $1010 \mathrm{mg} \cdot \mathrm{L}^{-1}$ sodium $)$. Values are the average of five replicates. Vertical bars represent the SE of five measurements. $1 \mathrm{dS} \cdot \mathrm{m}^{-1}=1 \mathrm{mmho} / \mathrm{cm}, 1 \mathrm{mg} \cdot \mathrm{L}^{-1}=1 \mathrm{ppm}, 1 \mathrm{bar}=100 \mathrm{kPa}$.

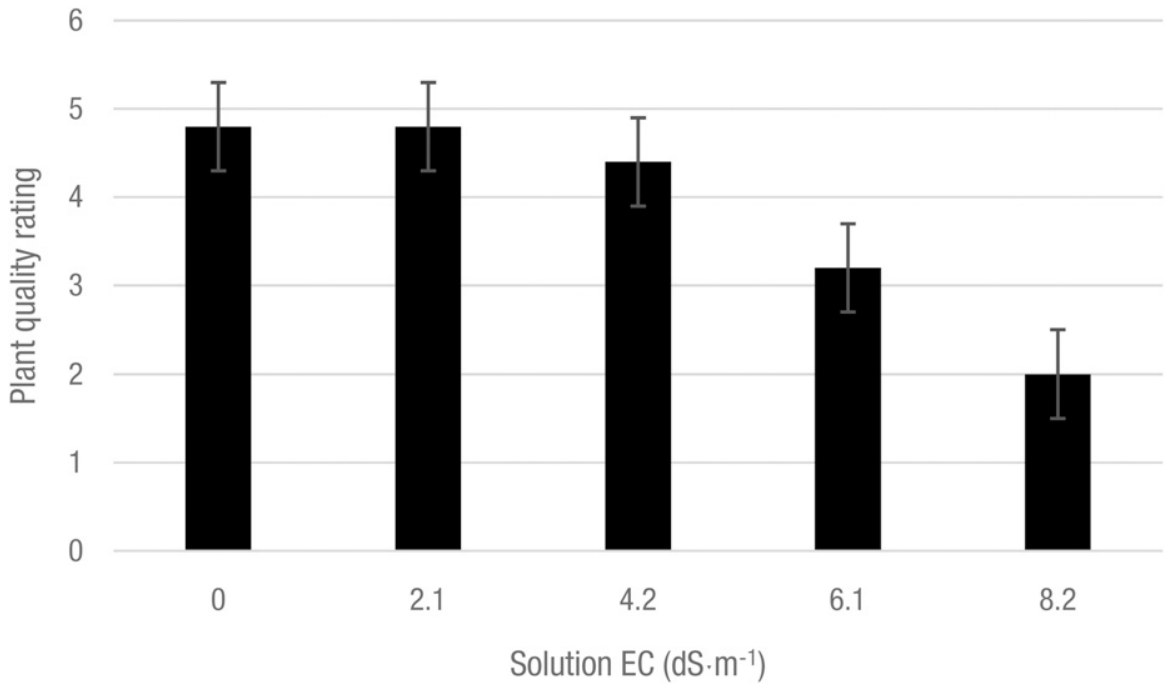

Fig. 2. Final plant quality rating of sea hibiscus after $14 \mathrm{~d}$ grown in deionized water with salt added to create an electrical conductivity (EC) of $0,2.1,4.2,6.1$ or $8.2 \mathrm{dS} \cdot \mathrm{m}^{-1}\left(0,240,420,510\right.$, or $1010 \mathrm{mg} \cdot \mathrm{L}^{-1}$ sodium $)$. Quality was rated on a scale of 5 to 1 , with 5 = plants not wilted and no visible necrosis; 4 = plants with slight wilting, no necrosis; 3 = plants wilted with necrosis; $2=$ wilted plants with significant necrosis; and 1 = plants dead. Values are the average of five replicates. Vertical bars represent the $\mathrm{SE}$ of five measurements. $1 \mathrm{dS} \cdot \mathrm{m}^{-1}=1 \mathrm{mmho} / \mathrm{cm}$, $1 \mathrm{mg} \cdot \mathrm{L}^{-1}=1 \mathrm{ppm}$.

(Gladware $^{\circledR}$ Tall Entrée; Glad Products Co., Oakland, CA). One cutting was supported through a hole cut in the center of each lid placed on the container. Each container was filled with $1 \mathrm{~L}$ deionized water with $0,1,2$, 3 , or $4 \mathrm{~g}$ sea salt (All-Purpose Sea Salt; Morton Salt, Chicago, IL) to create an EC of $0,2.1,4.2,6.1$, or $8.2 \mathrm{dS} \cdot \mathrm{m}^{-1}$ (Na concentration of $0,240,420$, 610 , or $\left.1010 \mathrm{mg} \cdot \mathrm{L}^{-1}\right)$. No additional nutrients were added. EC was measured using a combination $\mathrm{pH} / \mathrm{EC}$ for $12 \mathrm{~h} / \mathrm{d}$ for $14 \mathrm{~d}$. Temperature was maintained at $21{ }^{\circ} \mathrm{C}$ in the laboratory and around plants. After $14 \mathrm{~d}$, plant quality was rated on a scale of 1 to 5 with $5=$ plants not wilted and no visible necrosis; $4=$ plants with slight wilting, no necrosis; 3 = plants wilted with necrosis; 2 = wilted plants with significant necrosis; and $1=$ plants dead.

Leaf water potential was measured at $0,6,24,48$, or $72 \mathrm{~h}$ after being placed into saline solutions. One leaf from the top of each plant was sampled at 8:00 AM and was placed in a pressure chamber (model 3000 pressure extractor PV200/ 300158; Soilmoisture Equipment Corp., Santa Barbara, CA) that used compressed nitrogen $\left(\mathrm{N}_{2}\right)$ gas with a maximum pressure of 40 bars.

ExPT. 2. Rooted cuttings of coleus, copper leaf, ficus, jasmine, and plumbago were placed into $42-\mathrm{fl} \mathrm{oz}$ containers as described in Expt. 1. Sea salt- $0,0.5,1,2,2.5$, or $3 \mathrm{~g}$-was added to $1 \mathrm{~L}$ deionized water to create solutions with an EC of 0.0 , $1.3,2.1,4.2,5.6$, or $6.1 \mathrm{dS} \cdot \mathrm{m}^{-1}(\mathrm{Na}$ concentration of $0,170,240,420$, 520 , or $610 \mathrm{mg} \cdot \mathrm{L}^{-1}$ ). There were 10 replicates per treatment of each plant. After $14 \mathrm{~d}$, we rated plant quality on a scale of 1 to 5 . Shoots and roots were harvested and placed in a forcedair oven set at $90^{\circ} \mathrm{C}$ until a constant weight was achieved to determine dry weight.

Data from Expts. 1 and 2 were analyzed separately. In Expt. 1, leaf water potential was analyzed using analysis of variance (ANOVA) [PROC GLM (SAS version 9.2; SAS Institute, Cary, NC)] with factors for replication, time, and treatment (salt level). Plant quality for both experiments and shoot dry weight, root dry weight, and shoot:root ratio in Expt. 2 were analyzed using ANOVA with comparisons between salt treatments performed using Tukey-Kramer's test. Both experiments were repeated to verify results. Because the results were not different between the repeats of each experiment, the data were pooled.

\section{Results and discussion}

ExPT. 1. Placing sea hibiscus cuttings into solutions with an EC greater than $4.2 \mathrm{dS} \cdot \mathrm{m}^{-1}\left(>420 \mathrm{mg} \cdot \mathrm{L}^{-1}\right.$ $\mathrm{Na})$ resulted in decreased leaf water potential and plant quality (Figs. I 
Table 1. Final visual plant quality of coleus, copperleaf, ficus, jasmine, and plumbago plants after $14 \mathrm{~d}$ in deionized water with salt added to create solutions with increasing electrical conductivity (EC) and sodium (Na) concentrations.

\begin{tabular}{lcccccc}
\hline \multirow{2}{*}{$\begin{array}{l}\text { Solution EC } \\
\left(\mathbf{d S} \cdot \mathbf{m}^{-\mathbf{1}}\right)^{\mathbf{z}}\end{array}$} & $\begin{array}{c}\text { Solution Na } \\
\left(\mathbf{m g} \cdot \mathbf{L}^{-\mathbf{1}}\right)^{\mathbf{z}}\end{array}$ & \multicolumn{5}{c}{ Plant quality rating $(\mathbf{1 - 5} \text { scale })^{\mathrm{y}}$} \\
\cline { 3 - 7 } & 0 & $3.5 \mathrm{a}^{\mathrm{x}}$ & $3.5 \mathrm{a}$ & $4.0 \mathrm{a}$ & $3.3 \mathrm{a}$ & $4.2 \mathrm{a}$ \\
0.0 & 170 & $3.7 \mathrm{a}$ & $3.3 \mathrm{a}$ & $3.8 \mathrm{a}$ & $3.1 \mathrm{ab}$ & $3.3 \mathrm{~b}$ \\
1.3 & 240 & $2.6 \mathrm{~b}$ & $3.7 \mathrm{a}$ & $3.6 \mathrm{a}$ & $3.0 \mathrm{ab}$ & $3.0 \mathrm{~b}$ \\
2.1 & 420 & $2.2 \mathrm{~b}$ & $3.7 \mathrm{a}$ & $3.7 \mathrm{a}$ & $2.7 \mathrm{bc}$ & $2.7 \mathrm{c}$ \\
4.2 & 520 & $1.7 \mathrm{c}$ & $1.7 \mathrm{~b}$ & $1.7 \mathrm{~b}$ & $2.0 \mathrm{c}$ & $2.1 \mathrm{c}$ \\
5.6 & 610 & $1.2 \mathrm{c}$ & $1.1 \mathrm{~b}$ & $1.3 \mathrm{~b}$ & $2.0 \mathrm{c}$ & $2.1 \mathrm{c}$ \\
6.1 & & & &
\end{tabular}

${ }^{\mathrm{z}} 1 \mathrm{dS} \cdot \mathrm{m}^{-1}=1 \mathrm{mmho} / \mathrm{cm}, \mathrm{lmg} \cdot \mathrm{L}^{-1}=1 \mathrm{ppm}$

${ }^{y_{5}}=$ plants not wilted and no visible necrosis; $4=$ plants with slight wilting, no necrosis; $3=$ plants wilted with necrosis; $2=$ wilted plants with significant necrosis; $1=$ plants dead. Values are averaged for 10 replicates.

${ }^{x}$ Means followed by the same lowercase letter within a column are not significantly different by Tukey's method at $\alpha=0.05$.

Table 2. Final shoot dry weight, root dry weight, and shoot:root ratio of coleus, copperleaf, ficus, jasmine, and plumbago after $14 \mathrm{~d}$ in deionized water with salt added to create solutions with increasing electrical conductivity (EC) and sodium $(\mathrm{Na})$ concentrations.

\begin{tabular}{|c|c|c|c|c|c|c|}
\hline $\begin{array}{l}\text { Solution EC } \\
\left(\mathrm{dS} \cdot \mathbf{m}^{-1}\right)^{\mathrm{z}}\end{array}$ & $\begin{array}{c}\text { Solution Na } \\
\left(\mathrm{mg} \cdot \mathrm{L}^{-1}\right)^{\mathrm{z}}\end{array}$ & Coleus & Copperleaf & Ficus & Jasmine & Plumbago \\
\hline \multicolumn{7}{|c|}{ Shoot dry wt $(g)^{z}$} \\
\hline 0.0 & 0 & $5.38 \mathrm{a}^{\mathrm{y}}$ & $10.76 \mathrm{a}$ & $8.50 \mathrm{a}$ & $12.78 \mathrm{a}$ & $10.00 \mathrm{a}$ \\
\hline 1.3 & 170 & $5.40 \mathrm{a}$ & $10.68 \mathrm{a}$ & $8.02 \mathrm{a}$ & $12.56 \mathrm{a}$ & $9.99 \mathrm{a}$ \\
\hline 2.1 & 240 & $5.27 \mathrm{~b}$ & $10.65 \mathrm{a}$ & $7.98 \mathrm{a}$ & $12.39 \mathrm{a}$ & $9.96 \mathrm{a}$ \\
\hline 4.2 & 420 & $5.13 \mathrm{bc}$ & $10.66 \mathrm{a}$ & $7.97 \mathrm{a}$ & $10.21 \mathrm{~b}$ & $9.22 \mathrm{~b}$ \\
\hline 5.6 & 520 & $5.07 \mathrm{c}$ & $8.57 \mathrm{~b}$ & $6.13 \mathrm{~b}$ & $10.07 \mathrm{~b}$ & $9.10 \mathrm{~b}$ \\
\hline 6.1 & 610 & $4.31 \mathrm{c}$ & $8.46 \mathrm{~b}$ & $6.02 \mathrm{~b}$ & $9.89 \mathrm{~b}$ & $9.12 \mathrm{~b}$ \\
\hline \multicolumn{7}{|c|}{ Root dry wt $(g)^{z}$} \\
\hline 0.0 & 0 & $5.27 \mathrm{a}$ & $10.22 \mathrm{a}$ & $6.98 \mathrm{a}$ & $9.76 \mathrm{a}$ & $8.62 \mathrm{a}$ \\
\hline 1.3 & 170 & $5.21 \mathrm{a}$ & $10.20 \mathrm{a}$ & $6.61 \mathrm{a}$ & $9.66 \mathrm{a}$ & $8.70 \mathrm{a}$ \\
\hline 2.1 & 240 & $5.12 \mathrm{~b}$ & $10.10 \mathrm{a}$ & $6.40 \mathrm{a}$ & $9.61 \mathrm{a}$ & $8.69 \mathrm{a}$ \\
\hline 4.2 & 420 & $5.14 \mathrm{~b}$ & $10.10 \mathrm{a}$ & $6.39 \mathrm{a}$ & $8.39 \mathrm{~b}$ & $8.57 \mathrm{~b}$ \\
\hline 5.6 & 520 & $5.16 \mathrm{~b}$ & $9.09 \mathrm{~b}$ & $6.18 \mathrm{~b}$ & $8.29 \mathrm{~b}$ & $8.58 \mathrm{~b}$ \\
\hline 6.1 & 610 & $5.13 \mathrm{~b}$ & $9.05 \mathrm{~b}$ & $6.08 \mathrm{~b}$ & $8.19 \mathrm{~b}$ & $8.58 \mathrm{~b}$ \\
\hline \multicolumn{7}{|c|}{ Shoot:root ratio $(\text { by wt })^{\mathrm{z}}$} \\
\hline 0.0 & 0 & $1.02 \mathrm{a}$ & $1.05 \mathrm{a}$ & $1.21 \mathrm{a}$ & $1.31 \mathrm{a}$ & $1.16 \mathrm{a}$ \\
\hline 1.3 & 170 & $1.04 \mathrm{a}$ & $1.05 \mathrm{a}$ & $1.21 \mathrm{a}$ & $1.30 \mathrm{a}$ & $1.15 \mathrm{a}$ \\
\hline 2.1 & 240 & $1.03 \mathrm{a}$ & $1.05 \mathrm{a}$ & $1.24 \mathrm{a}$ & $1.29 \mathrm{a}$ & $1.15 \mathrm{a}$ \\
\hline 4.2 & 420 & $0.99 \mathrm{~b}$ & $1.05 \mathrm{a}$ & $1.25 \mathrm{a}$ & $1.21 \mathrm{~b}$ & $1.08 \mathrm{~b}$ \\
\hline 5.6 & 520 & $0.98 \mathrm{~b}$ & $0.94 \mathrm{~b}$ & $0.99 \mathrm{~b}$ & $1.21 \mathrm{~b}$ & $1.06 \mathrm{~b}$ \\
\hline 6.1 & 610 & $0.84 \mathrm{~b}$ & $0.93 \mathrm{~b}$ & $0.99 \mathrm{~b}$ & $1.21 \mathrm{~b}$ & $1.06 \mathrm{~b}$ \\
\hline
\end{tabular}

${ }^{\mathrm{z}} 1 \mathrm{dS} \cdot \mathrm{m}^{-1}=1 \mathrm{mmho} / \mathrm{cm}, 1 \mathrm{mg} \cdot \mathrm{L}^{-1}=1 \mathrm{ppm}, 1 \mathrm{~g}=0.0353 \mathrm{oz}$. Values are averaged for 10 replicates.

${ }^{y}$ Means followed by the same lowercase letter within a column are not significantly different by Tukey's method at $\alpha=0.05$.

and 2). Sea hibiscus leaf water potential of plants in all solutions decreased during the first $24 \mathrm{~h}$ after being placed in solution (Fig. 1). After $48 \mathrm{~h}$, sea hibiscus plants in solutions with an EC of 2.1 and $4.2 \mathrm{dS} \cdot \mathrm{m}^{-1}(240$ and $420 \mathrm{mg} \cdot \mathrm{L}^{-1} \mathrm{Na}$ ) started to adjust and were not significantly different from the water potential of plants grown in $0 \mathrm{dS} \cdot \mathrm{m}^{-1}$. The leaf water potential of plants grown in solutions of EC 6.1 and $8.1 \mathrm{dS} \cdot \mathrm{m}^{-1}(\mathrm{Na}$ of 610 and 1010 $\mathrm{mg} \cdot \mathrm{L}^{-1}$ ) continued to decrease (Fig. 1). After $72 \mathrm{~h}$, the leaf water potential of plants in 6.1 and $8.2 \mathrm{dS} \cdot \mathrm{m}^{-1}$ was less than plants grown in $0,2.1$, or 4.2 $\mathrm{dS} \cdot \mathrm{m}^{-1}$ (Fig. 1). After $14 \mathrm{~d}$, sea hibiscus plants in solutions with an EC of 6.1 or $8.2 \mathrm{dS} \cdot \mathrm{m}^{-1}$ had reduced quality, showing signs of wilting and necrosis (Fig. 2). However, there was no difference in plant quality for plants grown in solutions with an EC of $0,2.1$, or $4.2 \mathrm{~d} S \cdot \mathrm{m}^{-1}$.
Because sea hibiscus has been classified as a high salt-tolerant plant (Broschat and Meerow, 1996), we suspect that other salt tolerance mechanisms such as the accumulation of inorganic ions $(\mathrm{Na})$ in the vacuole (Kamel, 2008) or the accumulation of compatible organic solutes, such as amino acids (e.g., proline), soluble sugars (e.g., sucrose), polyols (e.g., mannitol), and betaines (e.g., glycine betaine), in the cytoplasm may be involved in restoring osmotic balance inside the cells of sea hibiscus plants grown in solutions with an EC of 2.1 and $4.2 \mathrm{dS} \cdot \mathrm{m}^{-1}$. For example, halophytes have been reported to absorb large amounts of salt from the external solution, achieving greater osmotic concentration inside the cell than outside the cell to restore osmotic balance (Flowers and Colmer 2008; Levitt, 1980; Parida and Das 2005).

EXPT. 2. Based on results with sea hibiscus, plant quality was used as an indicator of changes in response to salt stress for low to moderate salttolerant plants. Plant quality, shoot dry weight, root dry weight, and shoot:root ratio of coleus, a low salttolerant plant, declined at EC levels greater than $1.3 \mathrm{dS} \cdot \mathrm{m}^{-1}\left(170 \mathrm{mg} \cdot \mathrm{L}^{-1}\right.$ $\mathrm{Na}$ ), whereas growth of jasmine (low salt tolerance) and plumbago (medium salt tolerance) declined at EC levels greater than $2.1 \mathrm{dS} \cdot \mathrm{m}^{-1}(240$ $\mathrm{mg} \cdot \mathrm{L}^{-1} \mathrm{Na}$ ) (Tables 1 and 2 ). However, growth of copperleaf (medium salt tolerance) and ficus (medium salt tolerance) declined at EC levels greater than $4.2 \mathrm{dS} \cdot \mathrm{m}^{-1}\left(420 \mathrm{mg} \cdot \mathrm{L}^{-1}\right.$ $\mathrm{Na})$. When substrate EC levels exceeded $2.9 \mathrm{mS} \cdot \mathrm{cm}^{-1}$ and substrate $\mathrm{Na}$ levels were greater than $146 \mathrm{ppm}$, greenhouse plants showed toxicity symptoms (Raudales and Dickson, 2019). Similar results conducted in compost amended with $\mathrm{NaCl}$ reported petunia (Petunia bybrid 'Blue Flash') growth reductions when $\mathrm{Na}$ exceeded $540 \mathrm{mg} \cdot \mathrm{L}^{-1}$ in the substrate, whereas geranium (Pelargonium zonale 'Pulsar Red') growth was reduced at a $\mathrm{Na}$ level greater than $780 \mathrm{mg} \cdot \mathrm{L}^{-1}$ in the substrate and primula (Primula obconica 'Juno Deeprose') at a $\mathrm{Na}$ level greater than $140 \mathrm{mg} \cdot \mathrm{L}^{-1}$ in the substrate (Weinhold and Scharpf, 1997). Differences between our results and these studies are likely a result of different plant species and a difference between 
growing plants in solutions vs. growing them in substrates. It was beyond the scope of this study to compare uptake of $\mathrm{Na}$ from substrates vs. solutions. However, these results reiterate that salt tolerance is highly variable.

The effects of salinity on plant growth may be the result of direct effects of ion toxicity or indirect effects on water potential (Al-Karaki, $2000 b$ ). Decreases in tomato (Solanum lycopersicum) growth with increasing salt concentrations showed a reduction in water uptake (Al-Karaki, 2000 b). One adaptive response to reduced water uptake is a decrease in shoot:root ratio to decrease shoot size when root activity is decreased by external factors (Al-Karaki, 2000a). A similar trend of reduced shoot:root ratio as salt increased was observed in our study.

Salt tolerance is a polygenic trait; plants vary in salt tolerance and in $\mathrm{Na}$ tolerance. Plants grow best when $\mathrm{Na}$ and salt levels are low, and growers should use water sources low in salts and $\mathrm{Na}$ (Raudales and Dickson, 2019). Reported guidelines for water quality show no hazards to plant growth when $\mathrm{Na}$ levels are less than 60 to $69 \mathrm{mg} \cdot \mathrm{L}^{-1}$ whereas a moderate hazard to plant growth is expected at $\mathrm{Na}$ levels of greater than 120 to 207 $\mathrm{mg} \cdot \mathrm{L}^{-1}$ (Peterson, 1996; Rolfe et al., 2000). However, what if growers do not have access to high-quality water? The question becomes: What are the upper EC and Na limits plants will tolerate and still grow? The method described was simple to set up using rooted cuttings and materials purchased from the grocery store, with results achieved in $14 \mathrm{~d}$. Based on our study, plants with a reported low salt tolerance tolerated EC and $\mathrm{Na}$ levels in irrigation water up to $1.3 \mathrm{dS} \cdot \mathrm{m}^{-1}$ $\left(170 \mathrm{mg} \cdot \mathrm{L}^{-1} \mathrm{Na}\right.$ ) whereas plants with moderate to high salt tolerance tolerated EC and Na levels up to 2.1 to 4.2 $\mathrm{dS} \cdot \mathrm{m}^{-1}$ and 240 to $420 \mathrm{mg} \cdot \mathrm{L}^{-1} \mathrm{Na}$, respectively. As important as plant response to increasing EC levels, our work highlights the importance of monitoring $\mathrm{Na}$ levels. Depending on the source of the salts, plants often tolerate EC levels greater than 2.1
$\mathrm{dS} \cdot \mathrm{m}^{-1}$, especially if it is from fertilizer solutions. However, plant tolerance to increasing $\mathrm{Na}$ levels appeared to be more detrimental. Our study reinforces the importance of monitoring both EC and Na. The results from our study are based on values for plants grown in solution and might vary in substrates irrigated with water high in salts and $\mathrm{Na}$.

\section{Literature cited}

Al-Karaki, G.N. 2000a. Growth, sodium, and potassium uptake and translocation in salt stressed tomato. J. Plant Nutr. 23:369-379.

Al-Karaki, G.N. 2000b. Growth, water use efficiency, and sodium and potassium acquisition by tomato cultivars grown under salt stress. J. Plant Nutr. 23:1-8.

Boursiac, Y., S. Chen, D.T. Luu, M. Sorieul, N. van den Dries, and C. Maurel. 2005 . Early effects of salinity on water transport in arabidopsis roots: Molecular and cellular features of aquaporin expression. Plant Physiol. 139:790-805.

Brister, G.H. and R.C. Schultz. 1981. The response of a southern Appalachia forest to waste water irrigation. J. Environ. Qual. 10:148-153.

Broschat, T.K. and A.W. Meerow. 1996. Betrock's reference guide to Florida landscape plants. Betrock Information Systems, Hollywood, FL.

Day, A.D., J.A. McFadyen, T.C. Tucker, and C.B. Cluff. 1981. Effects of municipal waste water on yield and quality of cotton. J. Environ. Qual. 10:47-49.

Fitzpatrick, G.E. 1985. Container production of tropical trees using sewage effluent, incinerator ash and sludge compost. J. Environ. Hort. 3:123-125.

Fitzpatrick, G.E., H. Donselmann, and N.S. Carter. 1986. Interactive effects of sewage effluent irrigation and supplemental fertilization on container-grown trees. HortScience 21:92-93.

Flowers, T.J. and T.D. Colmer. 2008. Salinity tolerance in halophytes. New Phytol. 179:945-963.

Kamel, M. 2008. Osmotic adjustment in three succulent species of Zygophyllaceae. Afr. J. Ecol. 46:96-104.
Karleskint, J.L., J.P. Cooke, G. Fitzpatrick, and F. Jiang. 2011. The impacts of salinity on reuse irrigation. Florida Water Resourc. J. 63:4-9.

Levitt, J. 1980. Responses of plants to environmental stresses. Vol. II: Water, radiation, salt, and other stresses. Academic Press, New York, NY.

Luu, D.T. and C. Maurel. 2005. Aquaporins in a challenging environment: Molecular gears for adjusting plant water status. Plant Cell Environ. 28:85-96.

Munns, R. 2002. Comparative physiology of water and salt stress. Plant Cell Environ. 25:239-250.

Niu, G. and R.I. Cabrera. 2010. Growth and physiological responses of landscape plants to saline water irrigation: A review. HortScience 45:1605-1609.

Parida, A.K. and A.B. Das. 2005. Salt tolerance and salinity effects on plant: A review. Ecotoxicol. Environ. Saf. 60:324349.

Peterson, F.H. 1996. Water testing and interpretation, p. 31-49. In: D.W. Reed (ed.). Water, media, and nutrition for greenhouse crops. Ball Publications, Bataivia, IL.

Raudales, R.E. and R. Dickson. 2019. The roads that lead to salty water. GrowerTalks 82(10):54-57.

Rolfe, C., W. Yiasoumi, and E. Keskula. 2000. Managing water in plant nurseries. 2nd ed. NSW Agriculture, Orange, NSW, Australia.

Tournaire-Roux, C., M. Sutka, H. Javot, E. Gout, P. Gerbeau, D.T. Luu, R. Bligny, and C. Maurel. 2003. Cytosolic $\mathrm{pH}$ regulates root water transport during anoxic stress through gating of aquaporins. Nature 425:393-397.

Weinhold, F. and H.C. Scharpf. 1997. Tolerance of ornamental plants to salt, sodium, and chloride in potting substrates containing compost made of separately collected organic residues. Acta Hort. 450:221-228.

Yeager, T., C. Larsen, J. von Merveldt, and T. Irani. 2009. Use of reclaimed water for irrigation in container nurseries. Univ. Florida, Inst. Food Agr. Sci., Florida Coop. Ext. Serv., ENH 1119. 